\section{個別分散空調システム最適運転 制御法の開発}

\section{DEVELOPMENT OF OPTIMAL OPERATION CONTROL FOR MULTI- SPLIT TYPE AIR-CONDITIONING SYSTEM}

藤村昌弘

松下直幹 $* 2$

キーワード :

個別分散空調システム, EHP, 最適制御, COP 向上, システム開発

Keywords:

Multi-split type air-conditioning system, EHP, Optimal operation control, COP improvement, System development
Masahiro FUJIMURA $-* 1 \quad$ Naomiki MATUSHITA $-* 2$

We developed a system that can send orders from outside controller to the multi-split type air-conditioning system (EHP). Using this system, optimal operation control method for EHP was developed and installed into an office building. This control method improves COP of the EHP and reduces the excessive operation of the outside air processing unit. In this report, we installed this control method into an office building and verified its performance comprehensively.

\section{1. はじめに}

中小規模建物の多くで採用される電気式空気熱源ヒートポンプビ ル用マルチェアコン (以下, EHP) は, その制御内容が機器メーカー 独自の方式となっており, 機器本体で制御が完結していることもあ り, 設備設計者の意図する運転を容易に実現できない場合が多い. 数少ない事例として, 勝俣らが行ったシーケンサのアナログ制御に よる EHP と地中熱空調システムの同時制御 ${ }^{1)}$ があるが，制御対象は 室内機の $\mathrm{ON} / \mathrm{OFF}$ や運転時間設定に限られており, システム全体の 最適運転という観点では課題が残る.

このような背景から, 本研究では, EHP に対して外部のコントロ ーラから指令を与え, 自由度の高い運転制御を実現できるシステム を開発した。また, 本システムを用いて, EHP を高効率な負荷率帯 で運転させる “EHP 高効率運転制御” 開発し, 室内負荷処理用 EHP の運転効率向上を目指した。ささらに, 外気処理用 EHP の過剩な運転 を適正化する “外気処理機温湿度制御”, $\mathrm{CO}_{2}$ 濃度を判断基準として 外気導入量の低減を行う “ $\mathrm{CO}_{2}$ 制御” によって空調システム全体で電 力量削減を図った。これら EHP 高効率運転制御 - 外気処理機温湿度 制御・ $\mathrm{CO}_{2}$ 制御をすべて同時に行う制御を “EHP 最適運転制御” と称 する.

本報では，開発したシステムおよび制御の概要を説明するととも に，実物件に導入した結果についてまとめる.

\section{2. 制御システム概要}

開発した制御システムの概要図を図 1 に示寸。図中の破線は既存 システムを，実線が EHP 最適運転制御を実現するために追加した制 御システムを意味する. データ収集サーバは外気温度と電力量を計 測してデータを蓄積している.

制御システムの入出力情報を表 1 にまとめる. 特徵は, 室外機か
ら処理熱量を取得できる点と，停止，40\%，70\%，開放の 4Step で圧 縮機の回転数を下げて室外機に出力制限を与えることができる点で

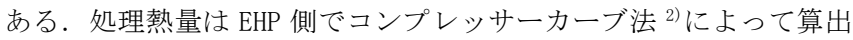
した值であり，メーカーの協力により取得できるようになった．

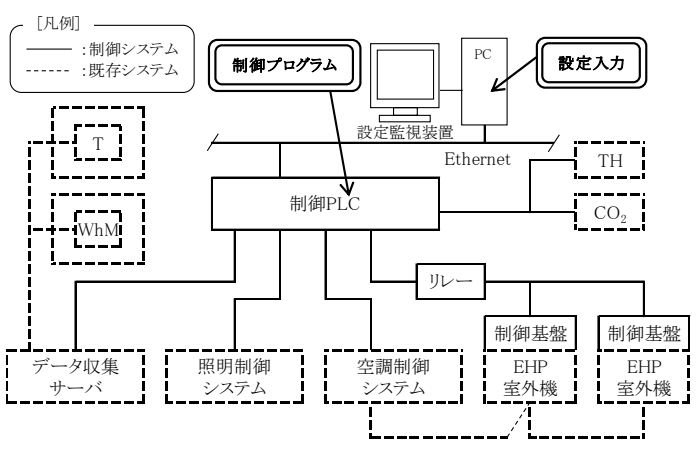

図 1 システムの概要図

表 1 システム入出力情報

\begin{tabular}{|c|c|c|c|}
\hline 機器種別 & 入出力* & ポイント名 & 内容 \\
\hline \multirow{6}{*}{ 室内機 } & \multirow{4}{*}{ 入力 } & 発停状態 $(=$ 運転状態) & 運転 / 停止 \\
\hline & & 運転モード & 冷房/暖房/送風/ドライ/自動 \\
\hline & & 室温 (吸込温度) & $-50.0 \sim 100^{\circ} \mathrm{C}$ \\
\hline & & 設定温度 & $15.0 \sim 35.0^{\circ} \mathrm{C}$ \\
\hline & \multirow{2}{*}{ 出力 } & 発停指令 & 運転 / 停止 \\
\hline & & 設定温度 & $15.0 \sim 35.0^{\circ} \mathrm{C}$ \\
\hline \multirow{7}{*}{ 室外機 } & \multirow{6}{*}{ 入力 } & 能力(=処理熱量) & $n n$ 時から +1 時までの 1 時間の積算値, 毎時 00 分に算出 \\
\hline & & $\mathrm{COP}$ & 1時間の平均値, $0.0 \sim 9.9$, 毎時 00 分に算出 \\
\hline & & 電流 & 電流値 $(0.0-999.9 \mathrm{~A}), 1$ 分毎に算出 \\
\hline & & 定格電流比率 & 0-300\%，1分毎に算出，定格電流に対する現在電流比 \\
\hline & & 電力 & データ収集サーバより1分毎に算出 \\
\hline & & 能力積算 & 能力 $(=$ 処理熱量 $) の$ 積算カウンタタ \\
\hline & 出力 & 出力上限値設定 & 停止, $40 \%, 70 \%$, 開放の4Step \\
\hline \multirow[b]{2}{*}{ (2) } & \multirow{2}{*}{ 入力 } & 湿度 & $0.0 \sim 100.0 \%$ \\
\hline & & $\mathrm{CO}_{2}$ 濃度 & 400 2000ppm \\
\hline
\end{tabular}

3. 制御概要

\subsection{EHP 高効率制御}

図 2 に EHP 高効率制御の概要を示す. 図中の性能曲線は概念図で あり, 特定の機器の性能を示寸ものではない.

\footnotetext{
I Group Manager, Equipment and Information Systems Dept., Aleph Networks Corporation

Business General Manager, Aleph Networks Corporation

(株アノレネット設備情報システム部 グループマネージャ

（テ 531-0074 大阪市北区本庄東 2-3-12）

株アレフネット 事業統括部長
} 
対象とした EHP は負荷率 40\% 付近で COP が最大になり， $20 \%$ 以 下で効率が大きく低下寸る性能特性を持つ. また, EHP は空調負荷 が 40\%であっても, 運転出力は $40 \%$ 一定ではなく, 例えば $20 〜 80 \%$ の 範囲で変動しながら運転する. そのため, $\mathrm{COP}$ の低い低負荷率や高 負荷率での運転が少なからず発生する.

これらの特性と傾向を踏まえて, EHP が高効率となる負荷率帯で の運転ができるだけ長くなるような制御手法を開発した，以下に制 御手法の概要を示す.

(1)室外機に出力上限指令を与えて出力を抑制する.

(2)出力抑制時に, 吸込み温度と設定温度の温度差が大きく

乘離した時には，出力制限を $1 \mathrm{Step}$ 上げる.

(3)吸込み温度と設定温度の乘離なく運転している場合には, 現状 の負荷に見合った出力上限となるように 1 Step を下げる.

(4)室外機出力が $20 \%$ 以下で, かつ, 吸込夕温度と設定温度の温度 差が小さい場合には，強制的に室外機を停止させて，低負荷率 領域での運転を回避する.

(1)〜 (4)の制御によって必要最小限の出力に制限する. 一般的に EHP の負荷率は $50 \%$ に満たない低負荷域に集中すると言われており 3), この制御によって, 負荷率 40\%での一定運転が増え, COP 向上に 繋がることが期待される.

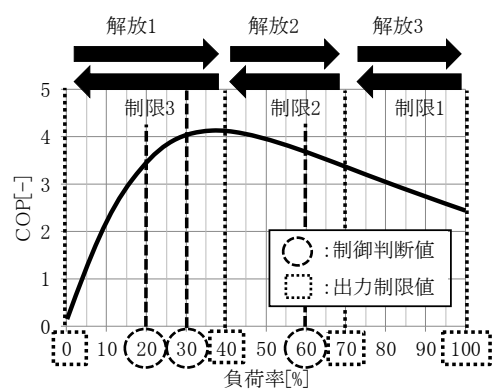

図 2 EHP 高効率制御の概要

\section{2 外気処理機温湿度制御}

全館 EHP の空調設備では, 外気処理のために室内負荷処理用とは 別に外気処理用 EHP を採用寸る場合がある. 今回対象とした外気処 理用 EHP は, 図 3 に示寸外気処理用 EHP 制御点での温度と固定設定 值 (冷房 $25^{\circ} \mathrm{C} \cdot$ 暖房 $21^{\circ} \mathrm{C}$ ) との大小関係で泠却加熱量を一律に決定 するため, 給気温度を制御できず, 必要以上に顕熱及び潜熱処理を行 う要因となる。 また, 加湿方式は滴下浸透式であるが, 湿度調節器 を適切に設置していないため, 湿度設定ができず加湿量は成り行き となっている。このような事例は一般にも散見される.

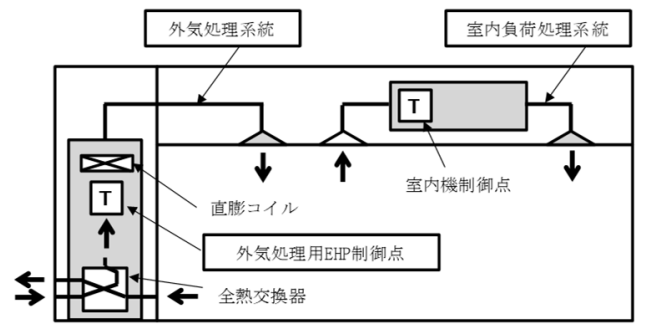

図 3 空調システム概要図

外気処理機温湿度制御は, 室内の温湿度が適正範囲となるように 外気処理用 EHP の室外機出力を調整する制御である。
暖房を例にした制御概要図を図 4 に示す，制御無効時は，全熱交 換器を通過した外気の温度と設定值の差によって, 室外機の出力が 制御されている. 外気は直膨コイルを通過後に加湿され, 吹出空気 の状態が決まる，全熱交換器を介して室内の影響を若干は受けるも のの，直接的には室温を制御対象としていないため，室内低負荷時 には，外気処理用 EHP が過剩に負荷処理する場合もある。実際に， 低負荷のため室内負荷処理用 EHP が送風運転しているにも関わらず, 外気処理用 EHP だけで室内温湿度が設定值を超える現象が見られた。

これに対して，温湿度制御有効時は室内の温湿度が設定值よりも 高い場合に，室外機の出力を抑制して直膨コイルによる温度上昇を 抑える，温度が低下寸ることで加湿量も減少し，吹出空気は温度・ 湿度ともに抑えられることになる。

なお，本制御は温度制御を優先し，湿度は温度が適正範囲である 場合にのみ制御判断に使用寸る.

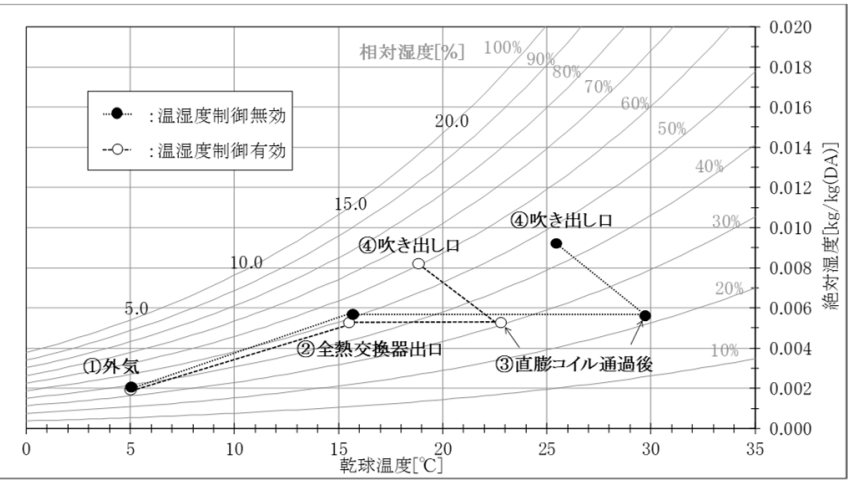

図 4 外気処理機温湿度制御概要図

\section{3 外気処理機 $\mathrm{CO}_{2}$ 制御}

室内 $\mathrm{CO}_{2}$ 濃度に応じた外気導入量の制御 $\left(\mathrm{CO}_{2}\right.$ 制御 $)$ は, EHP での 採用事例が少なく，特に複数の外気処理用 EHP の台数制御に踏み込 んだ事例は見られない。そこで，本研究では外部制御システムを活 用して，外気処理用 $\mathrm{EHP}$ 室内機の運転台数を増減する $\mathrm{CO}_{2}$ 制御を組 み込んだ. 2 台 1 組の構成における制御概要図を図 5 に示す.

$\mathrm{CO}_{2}$ 濃度が設定值を超えた場合には, 外気導入量が不足していると 判断して外気処理用 EHP 室内機の運転台数を増段する。一方, $\mathrm{CO}_{2}$ 濃 度が設定值を下回った場合には，外気処理用 EHP の室内機を減段す る. 室内の $\mathrm{CO}_{2}$ 濃度センサで制御する場合は全停止 $(0$ 台 $)$ まで減段 するが，還気ダクト内にセンサがある場合には， $\mathrm{CO}_{2}$ 濃度が出来なく なるため間欠運転を最小とする。

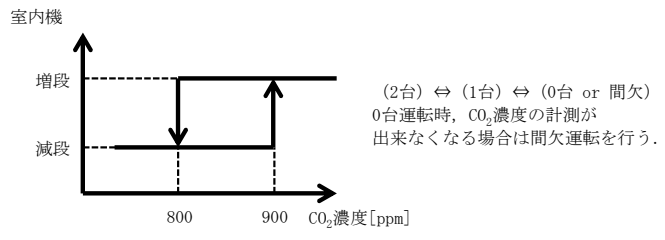

図 $5 \quad \mathrm{CO}_{2}$ 制御概要図

\section{4. 実物件への適用}

\section{1 物件概要}

実物件に前述の制御を導入し，EHP 最適運転制御の効果を検証し た. 表 2 に導入物件の概要を示す. 2014 年 8 月に竣工した新築の事 務所用途ビルであり, 空調システムとして全館 EHP を採用している. 
主要執務室の空調システムは図 3 に示すように, 室内負荷処理用 EHP と全熱交換器付の外気処理用 EHP からなる.

表 3 に空調システムの能力一覧を示す. 主に事務室系統の能力が 大きい室外機を制御対象としている. 室内機は天井埋込ダクト方式 であり, アネモ吹出しロが採用された。

表 2 物件概要

\begin{tabular}{l|l}
\hline 延床面積 & $7,337 \mathrm{~m}^{2}$ \\
\hline 建諧数 & 地上8階 \\
\hline 建物用途 & 事務所用途 \\
\hline 空調設備 & (空調)EHP方式、天井埋込ダタ卜接続形 \\
\cline { 2 - 3 } & (換気)外調機EHP、全熱交換器付 \\
\hline 照明設備 & Hf蛍光灯 (照度センサ少付)、LED照明 \\
\hline
\end{tabular}

表 3 制御対象空調システム能カー覧

\begin{tabular}{|c|c|c|c|c|c|c|c|}
\hline \multirow[b]{2}{*}{ 対象 } & \multirow[b]{2}{*}{ 階数 } & \multirow[b]{2}{*}{ 機器記号 } & \multirow[b]{2}{*}{ 系統 } & \multicolumn{4}{|c|}{ 能力 $[\mathrm{kW}]$} \\
\hline & & & & \multicolumn{2}{|c|}{ 冷房 } & \multicolumn{2}{|c|}{ 暖房 } \\
\hline \multirow{15}{*}{ 制御対象 } & \multirow{2}{*}{ 1階 } & ACP1-1 & 北側系統 & 69 & \multirow{2}{*}{103} & 78 & \multirow{2}{*}{103} \\
\hline & & ACP1-3 & 外気処理機 & 34 & & 38 & \\
\hline & \multirow{3}{*}{ 2階 } & $\mathrm{ACP} 2-1$ & 南側系統 & 45 & \multirow{3}{*}{135} & 50 & \multirow{3}{*}{135} \\
\hline & & ACP2-2 & 北側系統 & 56 & & 63 & \\
\hline & & ACP2-5 & 外気処理機 & 34 & & 38 & \\
\hline & \multirow{2}{*}{ 3階 } & АСР3-1 & 南側系統 & 56 & \multirow{2}{*}{84} & 63 & \multirow{2}{*}{84} \\
\hline & & АСР $3-3$ & 外気処理機 & 28 & & 28 & \\
\hline & \multirow{3}{*}{ 4階 } & ACP4-1 & 南側系統 & 56 & \multirow{3}{*}{118} & 63 & \multirow{3}{*}{118} \\
\hline & & ACP4-2 & 北側系統 & 34 & & 38 & \\
\hline & & ACP 4-3 & 外気処理機 & 28 & & 32 & \\
\hline & \multirow{2}{*}{ 5階 } & ACP5-1 & 南側系統 & 45 & \multirow[b]{2}{*}{73} & 50 & \multirow[b]{2}{*}{73} \\
\hline & & ACP5-5 & 外気処理機 & 28 & & 32 & \\
\hline & \multirow{2}{*}{ 6,7階 $\mid$} & ACP7-1 & 食堂系統 & 56 & - & 63 & - \\
\hline & & $\mathrm{ACP}-\mathrm{NW}-3$ & 外気処理機 & 45 & - & 50 & \multirow{2}{*}{$\frac{1}{83}$} \\
\hline & \multicolumn{3}{|c|}{ 合計 } & \multicolumn{2}{|c|}{613} & 683 & \\
\hline 制御対象外 & \multicolumn{3}{|c|}{ 合計 } & \multicolumn{2}{|c|}{321} & \multicolumn{2}{|c|}{367} \\
\hline
\end{tabular}

\section{2 制御効果}

制御効果を検証するにあたり，2015 年 4 月から 2016 年 3 月に制 御の有効無効を切り替えて検証を行った.

\section{2. 1 EHP 高効率制御による効果}

冷房期における $\mathrm{EHP}$ 高効率制御の効果を分析する. まず, 制御有 効日と無効日の運転出力の時系列変化を図 6 に示す. 運転出力は, 室外機電流值を定格電流值で除した定格電流比率で表している．制 御無効日には, 運転出力が大きく変動しているのに対して, 制御有 効日には, 出力上限值に沿った一定出力の運転がなされている. 11 時台と 13 時台に出力が $120 \%$ となっているのは, 機器保護のための 油戻し運転が作動したためである。制御有効日には, 出力抑制にも 関わらず，室温は設定值以下に保たれている. 制御無効日には特に 朝, 夕の室温が設定值より低くなり寸ぎる事象が見られた.
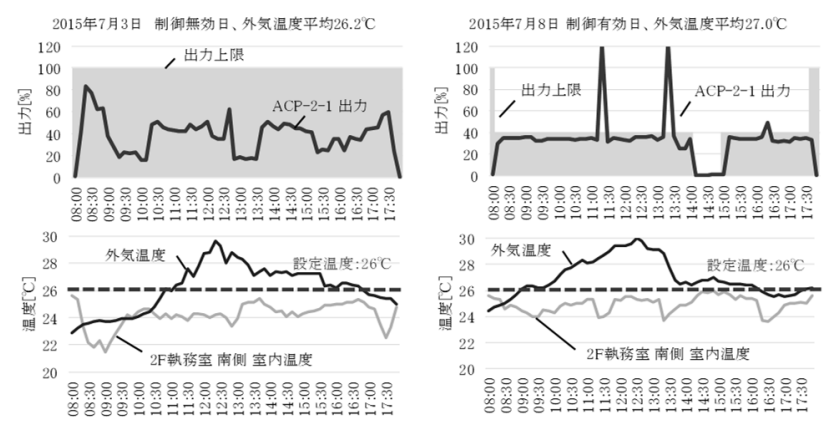

図 6 EHP 高効率制御有効 - 無効時の制御状況

図 7 に冷房期間 (7〜9月) 全体の負荷率の発生頻度を示す. 制御無 効時と比較して, 制御有効時では低負荷率帯 $(0 \sim 10 \%)$ が減少して, 効率の良い中負荷率帯 (30〜 40\%) が増加している. 効率の良い負荷率 帯での運転時間が増加したことが確認できた。

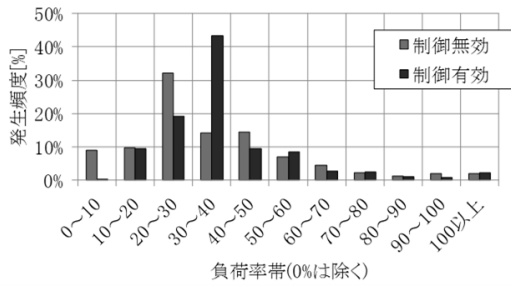

図 7 冷房期間 (7 9 月) 全体の負荷率の発生頻度

図 8 は, 制御有効日と無効日の冷媒の蒸発温度を示している. $0^{\circ} \mathrm{C}$ は制御無効時の標準蒸発温度を示し, 正の值は標準温度から上昇し た温度值を示す. 図より, 制御を有効にすると蒸発温度が上昇して いることがわかる. 本来, EHP 室外機は蒸発温度を一定に制御する が，出力制限のため蒸発温度を目標值まで下げることが出来ず，室 温に近づいたものと考えられる．蒸発温度の上昇は EHP の効率向上 の要因となる.

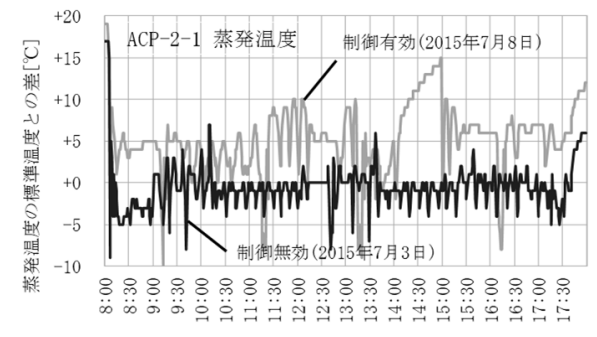

図 8 制御有効無効時の蒸発温度比較

制御有効時の COP を確認したところ, 図 9 に示寸ように無効時と 比較して冷房で $23.2 \%$, 暖房で $7.4 \%$ 向上が見られた. 暖房期の効 果が小さかった要因としては, 対象建物の断熱性能が優れており, 暖房負荷が小さかったことが考えられる. 元々出力 $40 \%$ 以下で運転 している時間が長く, 出力上限指令を与えても, $40 \%$ の一定運転は ほとんど生じず, 20\%以下の運転を回避した効果しか得られなかった。

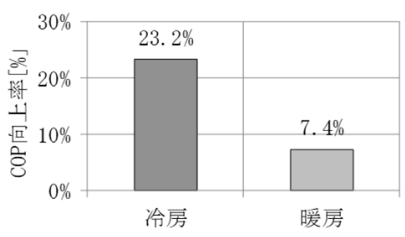

図 9 制御有效時の COP 向上率

\section{2.2 温湿度制御制御による効果}

温湿度制御有効・無効時の暖房代表日における室外機出力と室内 温湿度の推移を図 10 に示す。制御無効日には外気処理用 EHP は出 力 $100 \%$ 付近で運転し, 室温は設定值よりも高く推移し, 室湿度も上
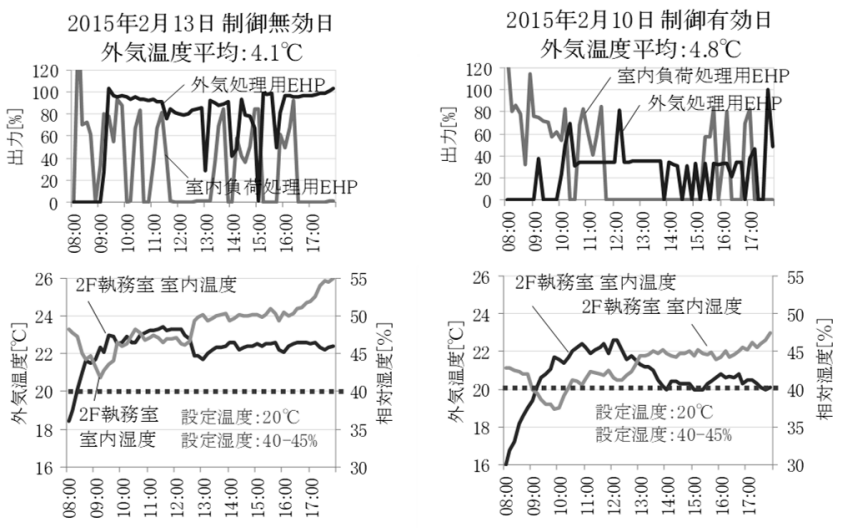

図 10 温湿度制御有効・無効時の制御状況 
昇を続けている。これに対し, 制御有効日には外気処理用 EHP の出 力は 40\%付近で抑えられ, 温湿度ともに設定值に近い值で推移して いる。

図 11 に代表日における EHP 室外機の日積算電力消費量を比較し て示す. 温湿度制御により, 外気処理用 EHP の電力消費量は $51.7 \mathrm{kWh}$ から $17.7 \mathrm{kWh}$ 一約 66\%削減された。一方で, 室内負荷処理用 EHP の 電力消費量が微増した.

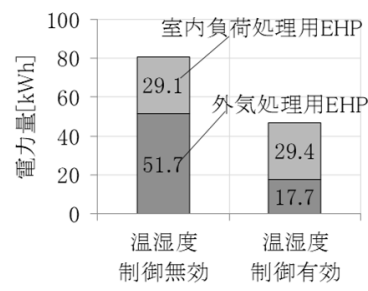

図 11 温湿度制御有効・無効時の電力消費量

\section{4. $2.3 \mathrm{CO}_{2}$ 制御による効果}

$\mathrm{CO}_{2}$ 制御を有効にした代表日の制御結果を図 12 に示す. $\mathrm{CO}_{2}$ 濃度が 低くなると減段し, 高くなると増段して $\mathrm{CO}_{2}$ 濃度を適正範囲に収ま るように制御している. その結果, 外気処理機室内機の運転時間を 制御無効時よりも $43 \%$ 減少させることができた.

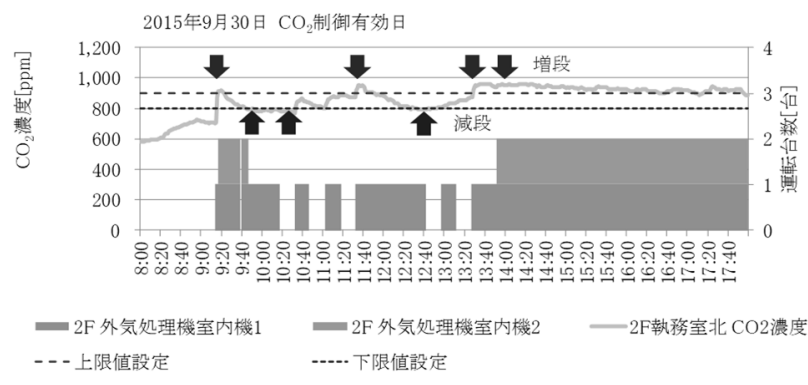

図 $12 \mathrm{CO}_{2}$ 制御有効時の外気処理用室内機の運転台数

\section{3 効果まとめ}

本節では，これまで検証してきた制御を同時に行った“EHP 最適 運転制御” の効果について確認する。図 13 に制御無効日を $100 \%$ と した制御有効日の処理熱量, 電力消費量, $\mathrm{COP}$ の比率を示す. 制御 有効日，無効日ともに冷暖負荷ピーク日を代表日とした．

EHP 最適運転制御を有効にすることで，処理熱量と電力消費量は ともに削減された。 EHP の運転効率も向上した結果, 冷房期は電力 消費量を 39\%削減, 暖房期は 47\%削減することが出来た.
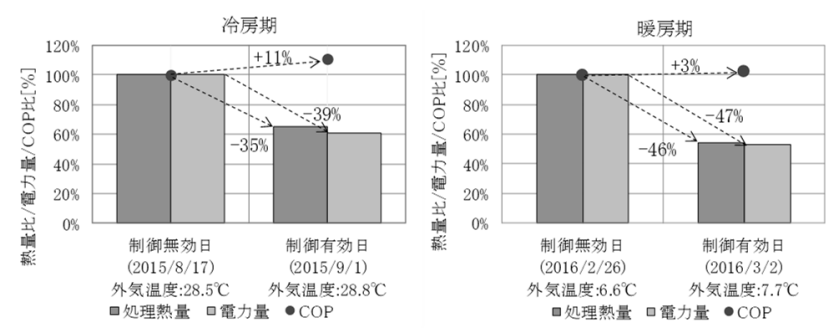

図 13 EHP 最適運転制御時による熱量 - 電力量 - COP の比率

次に, 室内環境について分析する. 数值データで問題なくとも, センサ位置や人の滞在場所によっては体感上の変化が感じられる可 能性がある。そこで, 執務者に対して冷房期にアンケートを実施し た（図 14）。アンケート項目は, 温度環境と湿度環境に関する満足
度, 実施日は, 制御無効日が 2015 年 8 月 27,28 日, 制御有効日が 2015 年 8 月 20,21 日である.

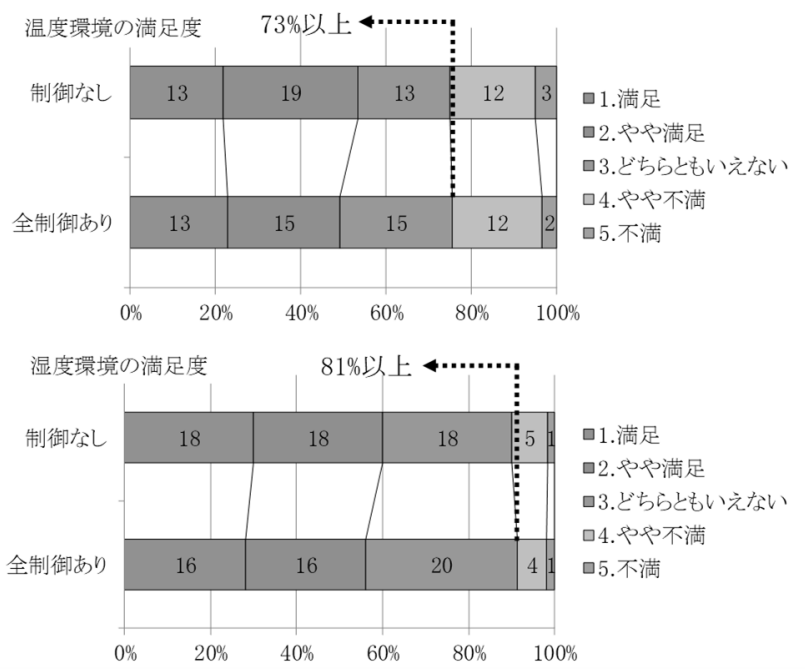

(回答者数: 制御無効日 $=60$ 人, 制御有効日 $=87$ 人)

図 14 EHP 最適運転制御時の室内環境アンケート結果

アンケート結果より，制御無効・有効どちらにおいても，温湿度 環境にやや不満・不満と回答した割合は $30 \%$ 未満であり, どちらと もいえないも含めて過半数は不満がないという回答であった.また， 制御を有効にしても，無効の場合に比べて不満の割合が増えるとい うこともなく, EHP 最適運転制御によって体感上でも室内環境の変 化は感じられないと評価できる，実験期間を通じて，EHP 最適運転 制御を要因と寸る不満やクレームはなかった.

\section{5. まとめ}

個別分散空調システムに対して，外部のコントローラから指令を 与えられるシステムと，当該システムを用いた EHP 最適運転制御を 開発し，その効果を検証した。

EHP 最適運転制御を行うことで, 空調負荷熱量は必要最小限とな り, EHP の運転効率も向上した，その結果，空調電力消費量は冷房 代表日で 39\%，暖房代表日で 47\%の削減率を達成できた。また，制御 を有効にしても室内環境が大きく変化することは無かった.

EHP 最適運転制御は，それぞれの制御を個別に導入することも出 来るため, 建物の空調設備の構成によって柔軟に制御を選択するこ とが出来る. 今後は, 本制御を水平展開して, 個別分散空調システ ムに対する省エネルギー対策を進めていきたい，また，EHP メーカ 一各社がこのようなシステム全体での省エネに取り組むとともに, 制御のオープン化に向かうことを強く望む.

\section{参考文献}

1)勝俣他:地中熱源と大気熱源エアコンを集中制御,川田技報 Vol.36, 19-3, 2017

2)下田:コンプレッサーカーブ法による空調能力計算とその応用,空気調和・衛 生工学会ワークショップ,個別分散空調の現状と性能評価,pp.6-9,2006.9 3)山田:18 事例におけるマルチパッケージ型空調機の実運用時性能評価,空気 調和・衛生工学会論文集,pp.1867-1870,2012.8

[2017 年 2 月 1 日原稿受理 2017 年 5 月 8 日採用決定］ 